\title{
PERTANIAN
}

\section{PENGARUH MACAM BAHAN TANAM TERHADAP PERTUMBUHAN DAN HASIL TIGA VARIETAS TALAS (Colocasia esculenta L.)}

\author{
Effect of Type of Planting Material on Growth and Yield of \\ Three Tar Varieties (Colocasia esculenta L.)
}

Oviaki Zelin dan Hidayat Bambang Setyawan

\author{
Program Studi Agroteknologi, Fakultas Pertanian, Universitas Jember \\ Jalan Kalimantan No. 37 Kampus Tegalboto, Sumbersari, Jember, 68121 \\ *E-mail: oviakizelin@gmail.com
}

\begin{abstract}
The growth and yield of taro plants can be influenced by the planting material used, and the use of improper types of planting material can cause plants to be unproductive according to potential yields. The use of planting materials derived from tubers is expected to increase the yield of taro. This study aims to determine the best type of planting material to increase the yield of taro. The experiments were carried out in the villages of Antirogo, Sumbersari, Jember, East Java with an altitude of \pm 89 meters above sea level starting in April 2018 to October 2018. The experiment used a Randomized Block Design (RBD) method with 2 treatment factors. Factor 1 is the type of planting material (B), B1: Bulbs; B2: Puppies; B3: Stolon. Factor 2 is taro variety (V), V1: Green Taro; B2: Brown Taro; B3: Purple Line Green Taro. Each repeated 4 times. The results showed that there was an interaction between the use of different types of planting material and varieties that had an effect on tuber weight per plant. The type of planting material has a significant effect on the number of tillers, leaf area, tuber weight, and tube diameter. Varieties significantly affect all observed variables. The treatment that gave the best results was planting material from tubers (B1) and Purple Line Green taro varieties (V3) with tuber yield per plant 362.58 grams ( \pm 14.5 tons $/$ ha).
\end{abstract}

Keywords: taro, planting material, varieties

\section{ABSTRAK}

Pertumbuhan dan hasil tanaman talas dapat dipengaruhi oleh bahan tanam yang digunakan, dan penggunaan macam bahan tanam yang kurang tepat dapat menyebabkan tanaman tidak produktif sesuai dengan hasil potensial. Penggunaan bahan tanam yang berasal dari umbi diharapkan dapat meningkatkan pertumbuhan dan hasil talas. Penelitian ini bertujuan untuk menentukan macam bahan tanam terbaik untuk meningkatkan pertumbuhan dan hasil talas. Percobaan dilakukan di desa Antirogo, Sumbersari, Jember, Jawa Timur dengan ketinggian \pm 89 mdpl dimulai pada bulan April 2018 sampai Oktober 2018. Percobaan menggunakan metode Rancangan Acak Kelompok (RAK) dengan 2 faktor perlakuan. Faktor 1 yaitu macam bahan tanam (B), B1: Umbi; B2: Anakan; B3: Stolon. Faktor 2 yaitu varietas talas (V), V1: Talas Hijau; V2: Talas Coklat; V3: Talas Hijau Garis Ungu. Perlakuan diulang sebanyak 4 kali. Hasil penelitian menunjukkan terdapat interaksi antara penggunaan macam bahan tanam dan varietas yang memberikan pengaruh terhadap bobot umbi per tanaman. Macam bahan tanam berpengaruh nyata terhadap jumlah anakan, luas daun, bobot umbi, dan diameter umbi. Varietas berpengaruh nyata terhadap seluruh variabel pengamatan. Perlakuan yang memberikan hasil terbaik yaitu bahan tanam dari umbi (B1) dan varietas talas Hijau Garis Ungu (V3) dengan hasil bobot umbi per tanaman 362,58 gram $( \pm 14,5$ ton/ha).

Kata kunci : talas, bahan tanam, varietas

How to citate: Oviaki Zelin, Hidayat Bambang Setyawan,. 2019. Pengaruh Jenis Bahan Tanam terhdap Hasil Tiga Varietas talas (Colocasia esculenta L.). Berkala Ilmiah Pertanian 2(3): 122-126.

\section{PENDAHULUAN}

Talas merupakan tanaman pangan yang hampir dapat tumbuh di seluruh daerah di Indonesia. Rahmawati et al (2012) menyatakan, produktivitas optimum talas mampu mencapai lebih dari 30 ton/hektar. Produktivitas talas di Indonesia hanya mencapai 9,52 ton/hektar pada tahun 2011 (Dinas Pertanian, 2012). Apabila dibandingkan dengan produktivitas di negara lain seperti Hawaii 37 ton/hektar, Nigeria 21,9 ton/hektar (Ubalua et al., 2016) dan China 16,8 ton/hektar (FAO, 2000), produktivitas talas di Indonesia termasuk masih rendah. Hal ini salah satunya dapat disebabkan oleh pemilihan dan penggunaan bahan tanam/bibit yang kurang baik (Djukri, 2003).

Bibit untuk budidaya talas dapat diperoleh dari berbagai macam bahan tanam seperti anakan, stolon dan umbi. Penanaman talas dengan bibit yang berasal dari umbi memberikan bobot per umbi dan hasil per hektar lebih tinggi daripada talas asal bibit anakan pada talas ungu (Istiqomah et al, 2010). Bahan tanam yang berasal dari anakan lebih sering digunakan oleh petani di Indonesia. Penggunaan stolon sebagai bahan tanam lebih jarang ditemukan dibandingkan dengan macam bahan tanam dari umbi dan anakan (Wang, 1983).

Varietas yang dibudidayakan di Indonesia diantaranya talas Hijau, talas Coklat dantalas Hijau Garis Ungu. Varietas talas Hijau paling banyak tersebar di Indonesia. Ukuran tanaman relatif kecil dengan warna hampir seluruhnya hijau, memiliki stolon panjang dan umbi berukuran sedang (Lebot et al, 2000). Talas Coklat berukuran relatif kecil dengan warna tangkai daun coklat tua dan umbi berukuran sedang (IPGRI, 1999). Varietas talas Hijau Garis Ungu berasal dari Sukabumi. Umbinya dapat mencapai panjang 12-18 cm dengan bobot minimum 100 gram dan maksimum 930 gram dengan ukuran tanaman lebih besar (Setyowati et al, 2007).

Melihat dari banyaknya potensi tanaman talas akan memberi peluang besar bagi pelaku usaha pertanian namun saat ini produksi talas masih tergolong rendah. Oleh karena itu, upaya yang perlu 
dilakukan adalah dengan memperbaiki sistem budidaya melalui penggunaan bahan tanam yang tepat serta jenis penggunaan varietas talas yang ditanam untuk mempercepat dan memperbaiki kuantitas hasil pada budidaya tanaman talas.

\section{BAHAN DAN METODE}

Waktu dan Tempat. Penelitian dilaksanakan di Desa Antirogo, Kecamatan Sumbersari, Kabupaten Jember pada ketinggian 89 m dpl. Dimulai pada bulan April 2018 sampai Oktober 2018.

Bahan dan Alat. Bahan yang digunakan dalam penelitian ini antara lain bibit talas yang berasal dari umbi, anakan, dan stolon yang terdiri dari tiga varietas (Hijau, Coklat, dan Hijau Garis Ungu), lahan persemaian, lahan pertanaman, dan pupuk kompos. Alat-alat yang digunakan dalam penelitian ini antara lain meteran, jangka sorong, kamera, alat tulis, dan timbangan analitik.

Metode Penelitian. Percobaan menggunakan metode Rancangan Acak Kelompok (RAK) dengan 2 faktor perlakuan. Faktor 1 yaitu macam bahan tanam (B), B1: Umbi; B2: Anakan; B3: Stolon. Faktor 2 yaitu varietas talas (V), V1: Talas Hijau; B2: Talas Coklat; B3: Talas Hijau Garis Ungu. Setiap faktor dikombinasikan menjadi 9 perlakuan dan diulang 4 kali dengan total 36 tanaman. Variebel yang diamati meliputi tinggi tanaman, jumlah anakan/stolon, jumlah daun per tanaman, luas daun, bobot umbi per tanaman dan diameter umbi. Tahapan pelaksanaan penelitian adalah sebagai berikut:

(1). Persiapan Bibit dan Penyemaian; bahan tanam yang digunakan terdiri dari 3 macam yaitu dari umbi, anakan dan stolon. (a). Bibit dari umbi; dilakukan dengan membelah umbi menjadi bagian tipis dengan setiap irisan minimal terdapat satu mata tunas. Mengangin-anginkan potongan umbi agar bagian dalam irisan menjadi kering. (b). Bibit dari anakan; dilakukan dengan mengambil bibit dari anakan/tunas yang telah memiliki umbi kecil. (c). Bibit dari stolon; dilakukan dengan mengambil bibit dari stolon yang tumbuh disekitar tanaman utama dengan cara memotong bagian yang menghubungkan tunas dengan tanaman utama. Bahan tanam yang telah didapat disemai dengan media tanah dalam polybag. Memelihara hingga daun terbentuk 2-3 helai.

(2). Penyiapan Lahan dan Penanaman; membajak atau mencangkul tanah sampai gembur dan membersihkan dari sisa tanaman atau rumput. Membuat bedengan dan lubang tanam dengan luas tiap bedengan $100 \mathrm{~cm} \times 50 \mathrm{~cm}$ pada lahan seluas $6 \mathrm{~m} \times 4,5 \mathrm{~m}$. Menambahkan pupuk kompos pada lubang tanam. Jarak tanam yang digunakan adalah $50 \mathrm{~cm}$ x $50 \mathrm{~cm}$. Memasukkan bibit ke dalam lubang tanam secara tegak lurus, kemudian menutup dengan tanah.

(3). Pemeliharaan dan Pemanenan; dengan melakukan penyulaman pada tanaman yang mati 15 HST, penyiangan 1 bulan sekali, pemupukan saat tanaman berumur 3 bulan, pengurangan anakan 150 HST, pengairan dan pengendalian hama penyakit. Pemanenan dilakuakan saat tanaman berumur 6 bulan.

\section{HASIL DAN PEMBAHASAN}

\section{Pengaruh Varietas dan Jenis Bahan Tanam Terhadap Pertumbuhan Tanaman}

Faktor varietas talas berpengaruh nyata terhadap tinggi tanaman talas pada umur 150 HST. Tanaman talas varietas Hijau Garis Ungu menunjukkan morfologi yang paling tinggi $(73.67 \mathrm{~cm})$ di bandingkan dengan dua varietas talas lainnya yakni varietas talas Hijau sebesar $69.88 \mathrm{~cm}$ dan talas Coklat sebesar 65,13 cm (Gambar 1).

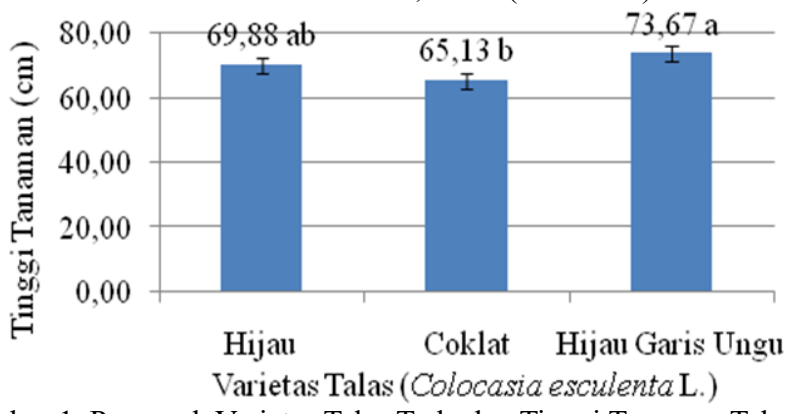

Gambar 1. Pengaruh Varietas Talas Terhadap Tinggi Tanaman Talas.
Perlakuan macam bahan tanam dan varietas yang digunakan memberikan pengaruh berbeda nyata terhadap jumlah anakan/stolon talas. Anakan/stolon talas dengan rata-rata paling banyak ditunjukkan oleh bahan tanam dari umbi (B1) sebesar 3,08 sedangkan rata-rata anakan/stolon terendah terdapat pada bahan tanam dari stolon yakni 1,92 (Gambar 2). Varietas yang menghasilkan anakan/stolon terbanyak yaitu talas Hijau (V1) dengan rata-rata 3,17 dan diikuti oleh V3 sebesar 2,17 serta jumlah anakan terkecil oleh talas Coklat (V3) sebanyak 2,00 (Gambar 3).

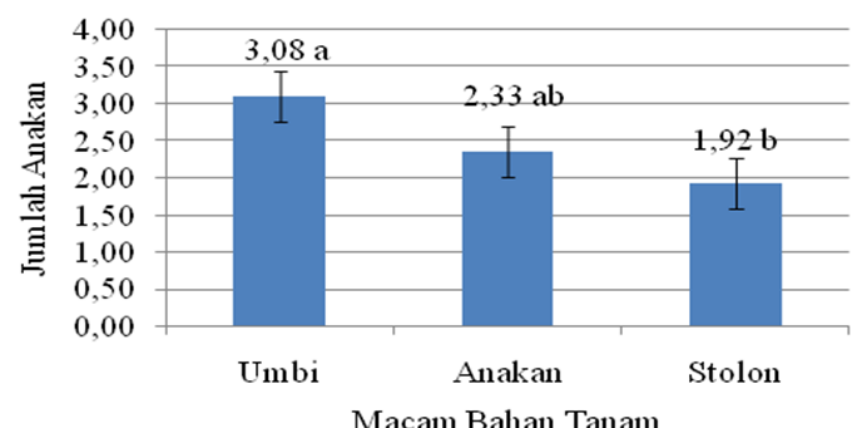

Gambar 2. Pengaruh Macam Bahan Tanam terhadap Pertumbuhan Jumlah Anakan/ Stolon Talas.

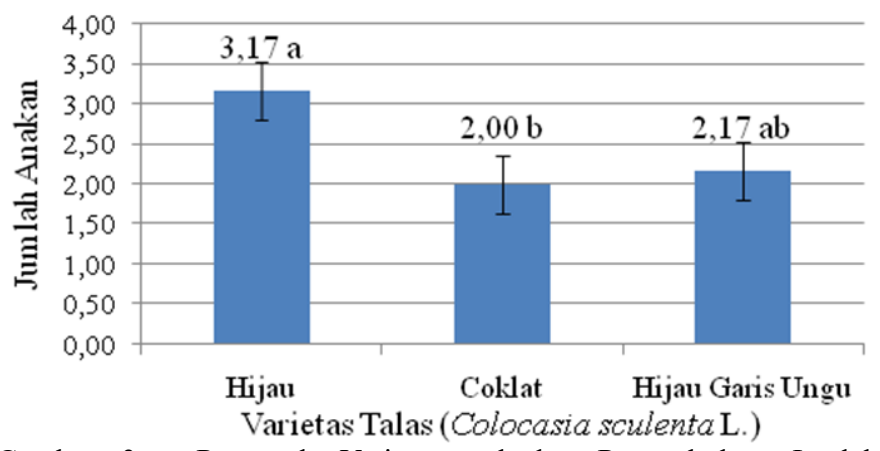

Gambar 3. Pengaruh Varietas terhadap Pertumbuhan Jumlah Anakan/Stolon Talas.

Perlakuan varietas talas yang berbeda juga menunjukkan pengaruh terhadap jumlah daun tanaman talas pada Gambar 4, menunjukkan bahwa V1 memiliki jumlah daun yang tertinggi yakni 5,50 helai daun di bandingkan dengan perlakuan V2 dan V3. Perlakuan macam bahan tanam dari umbi (B1) berpengaruh sangat nyata terhadap luas daun talas pada umur 6 bulan setelah tanam di bandingkan dengan perlakuan B2 dan B3. Luas daun tertinggi terdapat pada perlakuan umbi (B1) yakni $1361,31 \mathrm{~cm}^{2}$ (Gambar 5). V3 memiliki luas daun yang tertinggi yakni $1380,31 \mathrm{~cm}^{2}$ di bandingkan dengan perlakuan V1 dan V2 (Gambar 6).

Terdapat interaksi atara kedua perlakuan macam bahan tanam dan varietas talas terhadap bobot umbi talas per tanaman (Tabel 1). Hasil terbaik pada perlakuan bahan tanam berasal dari umbi (B1) di tunjukkan oleh perlakuan V3 $(362,58)$ yang berbeda nyata dengan perlakuan V1 $(262,92)$ sedangkan V1 berbeda tidak nyata dengan perlakuan V2 $(179,79)$. Hasil terbaik pada perlakuan bahan tanam dari anakan (B2) terdapat pada perlakuan V3 $(309,95)$ yang berbeda nyata dengan V1 $(203,73)$ dan V2 $(193,35)$. Hasil terbaik pada perlakuan bahan tanam dari stolon (B3) terdapat pada perlakuan V3 $(238,88)$ yang berbeda nyata dengan V1 $(162,13)$ serta V1 berbeda tidak nyata dengan V2 $(161,57)$. Hasil terbaik pada perlakuan varietas talas Hijau (V1) terdapat pada perlakuan bahan tanam B2 $(203,73)$ yang berbeda nyata dengan B1 $(262,92)$ dan B3 $(162,13)$. Hasil terbaik pada perlakuan varietas talas Coklat (V2) terdapat pada perlakuan bahan tanam B1 $(179,79)$ yang berbeda nyata dengan B2 $(193,35)$ dan B3 $(161,57)$. Hasil terbaik pada varietas talas Hijau Garis Ungu (V3) terdapat pada perlakuan B1 $(362,58)$ yang berbeda nyata dengan perlakuan B2 $(309,95)$ dan B3 $(238,88)$. 


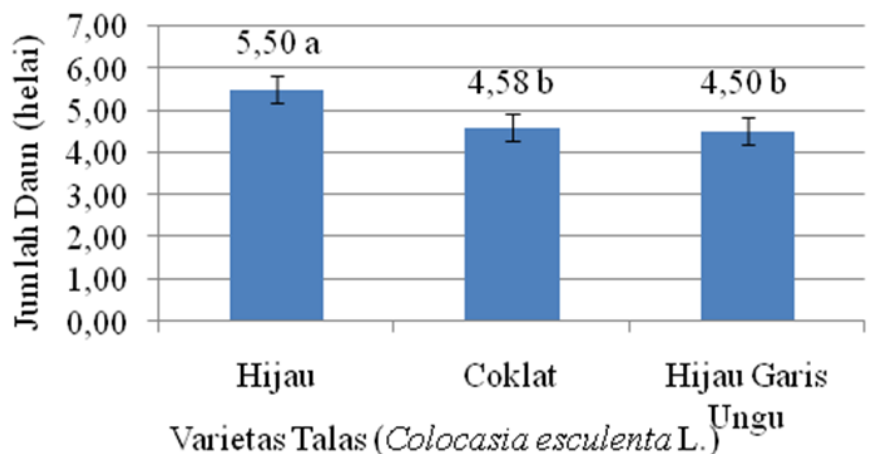

Gambar 4. Pengaruh Varietas Talas terhadap Pertumbuhan Jumlah Daun Talas.

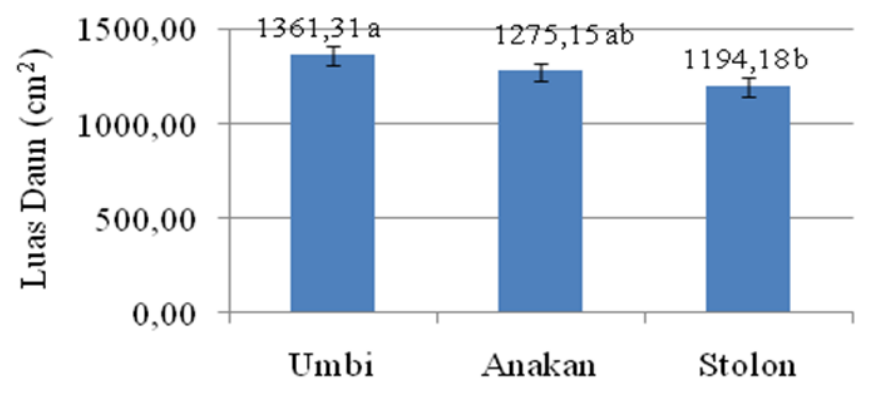

Macam Bahan Tanam

Gambar 5. Pengaruh Macam Bahan Tanam terhadap Luas Daun Talas.

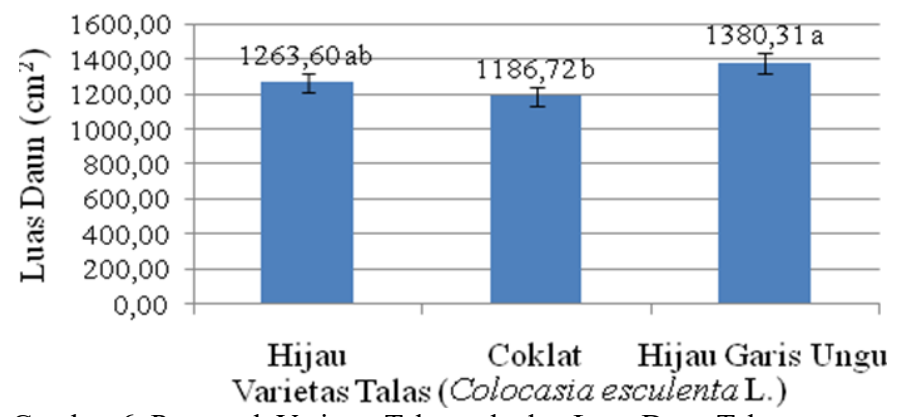

Gambar 6. Pengaruh Varietas Talas terhadap Luas Daun Talas.

Macam bahan tanam berpengaruh terhadap ukuran diameter umbi talas (Gambar 7). Perlakuan bahan tanam yang memiliki dimeter terbesar adalah B1 yaitu $7,82 \mathrm{~cm}$ sedangkan yang terkecil terdapat pada bahan tanam stolon (B3) yaitu $6,81 \mathrm{~cm}$. Perbedaan varietas talas juga berpengaruh terhadap besar diameter umbi talas (Gambar 8). Diameter umbi paling tinggi di tunjukkan oleh V3 $(8,07 \mathrm{~cm})$ di bandingkan dengan V1 $(7,31 \mathrm{~cm})$ dan V2 $(6,36 \mathrm{~cm})$.

Hasil terbaik secara keseluruhan terdapat pada varietas talas Hijau Garis Ungu (V3) dengan bahan tanam dari umbi. Hal ini sesuai dengan penelitian yang dilakukan oleh Tsedalu et al., (2014), yang menyatakan bahwa jenis bahan tanam memiliki pengaruh yang sangat signifikan terhadap rata-rata berat umbi per tanaman talas. Tercatat bahwa berat rata-rata berat umbi tertinggi per tanaman terdapat pada jenis bahan tanam dari umbi dari pada bahan tanam dari anakan. Hal ini dikarenakan pada penggunaan bahan tanam dari umbi menumbuhkan anakan lebih cepat bila dibandingkan bahan tanam dari anakan dan stolon. Anakan dan stolon yang tumbuh akan mendapatkan sumber energi dari tanaman induknya. Apabila anakan/stolon telah memiliki daun, anakan/stolon tersebut akan mendapatkan energi dari daunnya melalui fotosintsis (Eze et al., 2017) sehingga apabila anakan tumbuh lebih cepat dan telah menghasilkan sumber energi sendiri, tanaman utama akan menggunakan sumber energi yang dihasilkannya untuk pembesaran umbi. Seiring dengan peningkatan jumlah anakan/stolon, terjadi penurunan ukuran dan berat umbi per tanaman (Tsedalu et al., 2014), hal ini karena kompetisi untuk mendapatkan sumber daya untuk pertumbuhan tanaman akan semakin banyak sehingga dilakukan pembuangan beberapa anakan yang terlalu banyak dengan menyisakan 1-2 anakan saja.
Tabel 1. Interaksi Macam Bahan Tanam dengan Varietas Talas Terhadap Bobot Umbi Per Tanaman (g).

\begin{tabular}{lccc}
\hline \multirow{2}{*}{$\begin{array}{c}\text { Bahan } \\
\text { Tanam (B) }\end{array}$} & \multicolumn{3}{c}{ Varietas Talas (Colocasia esculenta L.) (V) } \\
\cline { 2 - 4 } & Hijau (V1) & Coklat (V2) & $\begin{array}{c}\text { Hijau Garis } \\
\text { Ungu (V3) }\end{array}$ \\
\hline Umbi (B1) & $262.92 \mathrm{a}$ & $179.79 \mathrm{ab}$ & $362.58 \mathrm{a}$ \\
& $\mathrm{B}$ & $\mathrm{B}$ & $\mathrm{A}$ \\
Anakan & $203.73 \mathrm{~b}$ & $193.35 \mathrm{a}$ & $309.95 \mathrm{~b}$ \\
(B2) & $\mathrm{B}$ & $\mathrm{C}$ & $\mathrm{A}$ \\
Stolon (B3) & $162.13 \mathrm{c}$ & $161.57 \mathrm{~b}$ & $238.88 \mathrm{c}$ \\
& $\mathrm{B}$ & $\mathrm{B}$ & $\mathrm{A}$ \\
\hline
\end{tabular}

Keterangan:

1. Angka yang diikuti huruf yang berbeda menunjukkan perbedaan yang nyata menurut $\mathrm{BNJ} \alpha=5 \%$

2. Notasi dengan huruf besar untuk pembacaan horizontal (B yang sama)

3. Notasi dengan huruf kecil untuk pembacaan vertikal (V yang sama)

Menurut Singh et al., (2013), varietas talas menyebabkan perbedaan karakter fisik pada bentuk umbi, berat umbi dan ukuran umbi talas. Secara statistik terdapat perbedaan yang signifikan pada umbi dan karakter fisik talas yang berbeda varietas. Menurut Setyowati dkk. (2007), umbi varietas Hijau Garis Ungu dapat mencapai panjang $12-18 \mathrm{~cm}$ dengan bobot minimum 100 gram dan maksimum 930 gram. Diantara ketiga varietas talas yang diamati, varietas talas Hijau Garis Ungu (V3) memiliki karakter fisik yang lebih besar bila dibandingkan talas Hijau dan talas Coklat sehingga menyebabkan hasil bobot umbi talas Hijau Garis Ungu (V3) lebih besar. Berdasarkan uraian diatas, penggunaan bahan tanam dari umbi (B1) pada varietas talas Hijau Garis Ungu (B1V3) mampu memberikan hasil bobot umbi per tanaman terbaik yaitu 362.58 gram.

Pertumbuhan tinggi pada tanaman dipengaruhi oleh faktor genetik (Susanti dkk, 2014). Pengaruh genetik merupakan pengaruh keturunan yang dimiliki oleh setiap varietas tanaman (Haryati dan Permadi, 2014). Hasil penelitian tinggi tanaman menunjukkan perbedaan yang nyata karena setiap varietas memiliki bawaan genetik masing-masing (Permanasari dan Dody, 2012). Pertumbuhan varietas talas Hijau Garis Ungu (V3) memiliki ukuran tanaman yang lebih besar bila dibandingkan dengan kedua verietas lainnya.

Menurut Istiqomah dkk., (2010), pengamatan pada jumlah anakan/stolon dari bahan tanam umbi cenderung menghasilkan anakan yang lebih banyak jika dibandingkan dengan perlakuan lainnya. Hal ini dikarenakan lebih banyak mata tunas yang mempunyai kesempatan untuk tumbuh pada umbi yang sudah dibelah. Bahan tanam dari umbi (B1) memiliki lebih banyak mata tunas pada tiap belahannya sedangkan bahan tanam dari anakan (B2) dan stolon (B3), hanya memiliki satu titik tumbuh utama sampai mata tunas samping tumbuh pada umbi yang telah membesar. Selain karena jumlah mata tunas, anakan dari setiap macam bahan tanam juga dipengaruhi oleh sumber energi yang digunakan untuk pertumbuhan tanaman. Menurut Sutoro \& Hadiatmi (2011), anakan yang berasal dari umbi memiliki sumber energi cadangan (karbohidrat) yang lebih banyak untuk digunakan bagi perkembangan tunas baru pada tanaman Garut.

Penelitian yang telah dilakukan menunjukkan hasil dimana dalam hal ini varietas yang menghasilkan anakan/stolon terbanyak yaitu talas Hijau (V1) dengan rata-rata 3.17. Jumlah anakan/stolon yang dihasilkan talas sangat erat kaitannya dengan faktor genetik dan lingkungan dengan kata lain, jumlah anakan dikendalikan oleh gen serta lingkungan tumbuh karena tanaman memerlukan kondisi lingkungan tumbuh yang optimal untuk dapat mengekspresikan potensi genetiknya (Nasrez et al., 2017).

Menurut Handayani (2003), menyatakan bahwa varietas mempengaruhi pertumbuhan jumlah daun, tinggi tanaman, diameter batang dan komponen hasil panen. Sama halnya menurut penelitian Eze et al., (2017), yang menyatakan bahwa jumlah daun pada tanaman talas secara signifikan dipengaruhi oleh genotipe selama periode penilaian pada beberapa varietas talas di Nigeria. Menurut Nasrez et al., (2017), terdapat korelasi positif dan signifikan antara luas daun dengan jumlah daun talas yang menunjukkan bahwa gen berhubungan erat dalam mengendalikan kedua parameter. 
Menurut Gebre et al., (2015), kepadatan populasi tanaman berpengaruh sangat signifikan terhadap jumlah pucuk dan luas daun. Hal serupa juga disampaikan oleh Tsedalu et al., (2014) bahwa jenis bahan tanam yang berasal dari umbi memberikan nilai paling tinggi dan berpengaruh signifikan terhadap jumlah daun, berat dan ukuran umbi serta luas daun per tanaman. Luas daun dari bahan tanam umbi lebih besar karena anakan/stolon tumbuh lebih cepat sehingga mampu menghasilkan energi secara terpisah dan tanaman utama dapat menggunakan energi yang dihasilkannya untuk pertumbuhan daun dan pembesaran umbi (Eze et al., 2017).

Ahmed et al., (2017), melaporkan bahwa luas daun berkaitan dengan kanopi karena apabila pertumbuhan luas daun berkurang, kanopi yang dihasilkan juga kecil. Hal ini dipengaruhi oleh faktor internal seperti genetik (varietas) dan faktor eksternal yang mempengaruhi proses fisiologis pada tanaman (Hossain et al., 2010). Varietas talas Hijau Garis Ungu (V3) memiliki luas daun lebih besar dibandingkan kedua varietas lainnya karena pada setiap helaian daun juga memiliki ukuran yang lebih besar.

Berdasarkan Gambar 1 menunjukkan bahwa macam bahan tanam berpengaruh terhadap ukuran diameter umbi talas. Perlakuan B1 berbeda sangat nyata dengan B2 dan B3. Perlakuan bahan tanam yang memiliki dimeter terbesar adalah B1 yaitu $7.82 \mathrm{~cm}$ sedangkan yang terkecil terdapat pada bahan tanam stolon (B3) yaitu $6.81 \mathrm{~cm}$. Menurut Tsedalu et al., (2014), penggunaan macam bahan tanam erat kaitannya dengan jumlah anakan, jumlah daun serta luas daun sehingga mempengaruhi ukuran dan berat umbi.

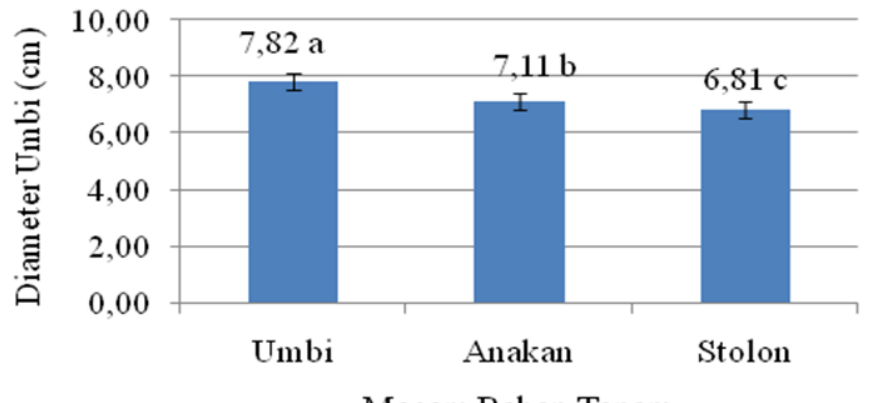

Macam Bahan Tanam

Gambar 7. Pengaruh Macam Bahan Tanam terhadap Diameter Umbi Talas.

Penelitian oleh Trimanto et al., (2010), menunjukkan bahwa bahan tanam mempengaruhi jumlah anakan yang dihasilkan tanaman talas dan berpengaruh signifikan terhadap diameter umbi. Hal ini disebabkan oleh semakin banyak anakan yang tumbuh maka kompetisi antar tanaman untuk mendapatkan sumber daya terutama untuk pembesaran umbi akan semakin tinggi. Oleh karena itu dilakukan penjarangan anakan yang terlalu banyak dengan menyisakan hanya 1-2 anakan saja. Menurut Eze et al., (2017), bahan tanam dari umbi memiliki diameter lebih besar karena anakan/stolon tumbuh lebih cepat dan dapat menghasilkan energi sendiri untuk pertumbuhannya sehingga tanaman utama dapat menggunakan energi yang dihasilkannya untuk pembesaran umbi.

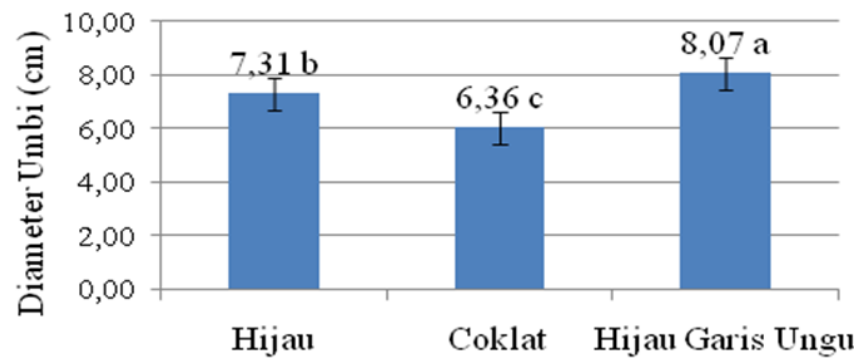

Varietas Talas (Colocasia esculenta L.)

Gambar 8. Pengaruh Varietas terhadap Diameter Umbi Talas

Perbedaan varietas talas juga berpengaruh terhadap besar diameter umbi talas. Berdasarkan Gambar 4.9, diameter umbi paling tinggi di tunjukkan oleh V3 $(8.07 \mathrm{~cm})$ di bandingkan dengan V1 $(7.31 \mathrm{~cm})$ dan V2 $(6.36 \mathrm{~cm})$. Respon pertambahan diameter pada setiap varietas talas berbeda karena bawaan genetiknya juga berbeda sehingga terjadi variasi dalam hal kecepatan pembelahan, multipikasi sel dan lain sebagainya untuk memunculkan peningkatan ukuran atau diameter umbi (Tewodros et al., 2017). Penelitian ini menunjukkan bahwa varietas talas Hijau Garis Ungu (V3) memberikan hasil tertinggi dengan menggunakan bahan tanam umbi (B1). Talas Hijau Garis Ungu merupakan talas dengan ukuran umbi yang relatif besar dibandingkan dengan talas Hijau dan talas Coklat. Menurut Wulansari dkk (2013), menyatakan bahwa umbi primer pada talas dapat berbentuk silinder yang panjangnya mencapai $30 \mathrm{~cm}$ dan berdiameter hingga $15 \mathrm{~cm}$.

\section{KESIMPULAN}

Kesimpulan dari penelitian ini yaitu terdapat pengaruh interaksi antara macam bahan tanam dan varietas talas terhadap bobot umbi per tanaman talas. Penggunaan bahan tanam dari umbi (B1) memberikan hasil tertinggi berbeda nyata pada variabel jumlah anakan/stolon (3.08), luas daun $\left(1361.31 \mathrm{~cm}^{2}\right)$, bobot umbi per tanaman $(362.58$ gram) dan diameter umbi $(7.82 \mathrm{~cm})$. Varietas talas yang ditanam memberikan hasil berbeda nyata pada semua variabel pengamatan. Varietas talas Hijau Garis Ungu (V3) memberikan hasil tertinggi pada variabel tinggi tanaman $(73.67 \mathrm{~cm})$, panjang tangkai daun $(60.33 \mathrm{~cm})$, luas daun $\left(1380.31 \mathrm{~cm}^{2}\right)$, bobot umbi per tanaman (362.58 gram) dan diameter umbi $(8.07 \mathrm{~cm})$. Kombinasi perlakuan tertinggi yakni bahan tanam dari umbi dan varietas Hijau Garis Ungu (B1V3) dengan ratarata bobot umbi per tanaman 362.58 gram $( \pm 14.5$ ton/ha).

\section{DAFTAR PUSTAKA}

Ahmed, B., M. Sultana, M. A. H. Chowdhury, S. Akhter and M. J. Alan. 2017. Growth and Yield Performance of Potato Varieties Under Different Planting Dates. Bangladesh Agron, 20(1): 2529.

Djukri. 2003. Efek Fisiologis Naungan Buatan pada Tanaman Talas (Colocasia esculenta (L) Schott). Pendidikan Matematika dan Sains, 2(8): 114-120.

Eze, C. E. Nwofia, G. E. Onyeka and Nwaogu, A. G. 2017. Growth and Tuber Yield Perfomance of Taro Landraces in the Face of Taro Leaf Blight (Phytophthora colocasiae Rachib) Outbreak in Nigeria. 13(3): 102-114.

Food and Agriculture Organization. 1999. Peculiarities of Taro Production in Specific Asia-Pacific Countries. Italy: FAO.

Gebre, A., B. Tesfaye and B. M. Kassahun. 2015. Effect of Corm Size and Plant Population Density on Corm Yield of Taro (Colocasia esculenta L.). Advanced Biological and Biomedical Research, 3(3): 309-315.

Hossain, M., Hossain, M. I., and Dey, T. K. 2010. Disease Free Seed Potato Production Through Seed Plot Technique At Farm Level. Agriculturists, 13(2): 120-132.

IPGRI. 1999. Descriptors for Taro (Colocasia esculenta). Italia: International Plant Genetic Resources Institute.

Istiqomah, N., Z. Arifin, dan A. Krismawati. 2010. Kajian Pembibitan Varietas Lokal Ungu dan Lokal Hijau terhadap Pertumbuhan dan Produksi Talas Malang. Prosiding Seminar Hasil Penelitian Tanaman Aneka Kacang dan Umbi 2010, 639-645.

Lebot, V., S. Hartati, N. T. Hue, N. V. Viet, N. H. Nghia, T.Okpul, J. Pardales, M. S. Prana, T. K. Prana, M. Thongjiem, C. M. Krieke, H. Vaneck, T.C. Yap and A. Ivancic. 2000. Genetic variation of taro (Colocasia esculenta) in South East Asia and Oceania. International Society for Tropical Root Crops, 10(16): 524-533.

Nasrez, A., Z. Syarif, and B. Satria. 2017. Identification of Plant Morphology of Taro as Potential Source of Carbohydrates. 
Advance Science Engineering Information Technology, 7(2): 573-579.

Permanasari, I. dan D. Kastono. 2012. Pertumbuhan Tumpangsari Jagung dan Kedelai pada Perbedaan Waktu tanam dan Pemangkasan Jagung. Agroteknologi, 3(1): 13-20.

Rahmawati, W., Y. A. Kusumastuti, dan N. Aryanti. 2012. Karakterisasi Pati Talas (Colocasia esculenta L.) sebagai Alternatif Sumber Pati Industri di Indonesia. Teknologi Kimia dan Industri, 1(1): 347-351.

Setyowati, M., I. Hanarida dan Sutoro. 2007. Karakteristik Umbi Plasma Nutfah Tanaman Talas (Colocasia esculenta). Buletin Plasma Nutfah, 13(2) : 49- 56.

Singh, P., A. Adube and L. Kumar. 2013. Physico-Chemical Properties of Six Varieties of Taro (Colocasia esculenta L. Schott) Flour. Experimental Chemistry, 8(2): 7-11.

Sutoro dan Hadiatmi. 2011. Perbanyakan Bibit Stek Umbi dan Uji Adaptabilitas Plasma Nutfah Garut (Marantha arundinaceae L.). Plasma Nutfah, 17(1): 1-8.

Tewodros, M., Neim S., Geta C. W., and A. Ashenafi. 2017. Effect of Mineral N and P Fertilizers on Storage Tuber Yield and Yield Components of Taro [Colocasia esculenta (L.) Schott] in Southwest Ethiopia. Bio Chemistry Research, 34(2): 688-695

Trimanto, Sajidan and Sugiyarto. 2010. Characterisation of Taro (Colocasia esculenta) Based on Morphological and Isozymic Patterns Markers. Bioscience, 2(1): 7-14.

Tsedalu, M., B. Tesfaye, and Y. Goa. 2014. Effect of Type of Planting Material and Population Density on Corm Yield and Yield Components of Taro (Colocasia Esculenta L.). Biology, Agriculture and Healthcare, 4(17): 124-137.

Ubalua, A. O., F. Ewa, and O. D. Okeagu. 2016. Potentials and Challenges of Sustainable Taro (Colocasia esculenta) Production in Nigeria. Applied Biology and Biotechnology, 4(1): 53-59.

Wang, J.K. 1983. A Review of Colocasia esculenta and Its Potential. Honolulu: University of Hawaii.

Wulansari, A., A. F. Martin, D. E. Rantau, dan T. M. Ermayanti. 2013. Perbanyakan beberapa Aksesi Talas (Colocasia esculenta (L.) Schott.) Diploid Secara Kultur Jaringan dan Konservasinya Mendukung Diversifikasi Pangan. Riset Pangan, Obat-obatan dan Lingkungan untuk Kesehatan, 27(2): 11-20. 